UDC $\quad 662.815: 539.217: 539.32$

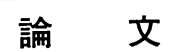

論文

\title{
不規則多孔体としてのコークスの力学的挙動に関する研究*
}

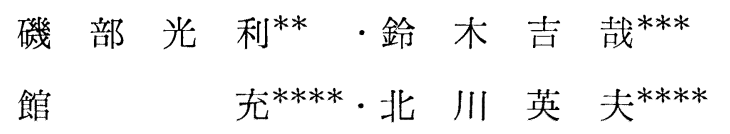

\section{Fundamental Study on the Mechanical Behavior of Coke as a Material with Rundomly Distributed Pores}

\author{
Mitsutoshi Isobe, Kichiya Suzuki, \\ Mitsuru TAte, and Hideo Kitagawa
}

\begin{abstract}
Synopsis:
A miniature bending test method was developed for measuring mechanical properties of coke with better accuracy. Mechanical properties of formed and conventional cokes at room temperature were measured by this method and the effects of pore on them were investigated, taking statistics into consideration. Deformation of a porous body was analysed by the finite element method combined with Monte Carlo method and an attempt was made to develop a method to estimate Young's modulus of coke matrix.

The results are as follows.

1) Linear correlation was found between Young's moduli of cokes and maximum bending stress and a possibility of estimating the strength from the measurements of elastic deformation was shown.

2) Young's modulus of coke decreased with increasing porosity. The decreasing rate of formed coke was different from that of conventional cokes.

3) Young's modulus of coke matrix was estimated by the new method from apparent Young's moduli including the effects of pores.

4) From a new viewpoint a comparison was made between the mechanical properties of formed coke and that of conventional one, using the Young's moduli of coke matrix obtained as above.
\end{abstract}

\section{1. 緒言}

高炉用コークスの強度特性の評価は, 従来ドラム強度 試験のような冷間での試験法に基づいて行われてきた が，近年熱間における強度特性を直接評価する試及も行 われるよらになつた。このためドラム強度を熱間あるい は熱間反応状態において測定する万法も開発されている が，現状では沉用の常温強度とこれら熱間強度との対応 が必ずしも十分明らかにされていないなど，いくつかの 問題点 ${ }^{1) 2}$ がある.

また原料炭事情の悪化の見通しとも関連して, 強粘結 岑を節減し，弱粘結炭ないし一般炭を活用する技術の一 環として成型コークス法が開発されてきているが，成型 コークスの品質管理を従来のドラム強度だけで行うこと
には問題がある。この場合ドラム強度の值が従来の室炬 コークスの水準を上回つたとしても，それは普通コーク スとの形状差や成型時の加压による硬化のためとも考え られ, 高炉内で室炉コークスと同等またはそれ以上の強 度を保障できるとは限らないからである。

総じて現行のコークス (冷間) 強度試験法は, 原料炭 種やュークス製造条件が大きく変わらない場合には, 歴 史的に試された有用性をもつているが，条件の大きな変 化のもとでは必ずしも十分とはいえない，こうして現行 試験法の域をこえて, ュークスの熱間強度を評価できる 万法の確立が求められており，これにこたえるため，コ 一クス強度についての基本的なアプローチが必要になつ ている.しかしュークスの強度指標ではなく，強度特性 そのものの評価のための試験法としては，井上らの共鳴

* 炤和 53 年 10 月本会講演大会にて発表 昭和 54 年 6 月 5 日受付 (Received June 5, 1979)

** 東京大学大学院 (現：（株）神戸製鋼所) (Graduate School, The University of Tokyo, Now Kobe Steel, Ltd.)

*** 東京大学生産技術研究所 (Institute of Industrial Science, The University of Tokyo)

**** 東京大学生産技術研究所工博 (Institute of Industrial Science, The University of Tokyo, 7-22-1 Roppongi Minato-ku 106) 
振動法によるヤング係数の測定 ${ }^{3)}$, 白石らのヌープ硬度 の測定4)，PATRICK 55) や宮川ら6) の間接的引張試験法 などがあるだけであり，しかも宮川ら6)のものを除いて は，各種成型及び室炉コークスの材質比較の研究に適用 された例は見られないよらである.

本研究はコークスの静的強度ないし耐荷力を基本的に 評価するという立場から，その冷間にお洔る基礎的な機 械的性質を調べること，およびそのための試験方法を開 発することをめざしたものである。このためまず新たに ミニチュア 4 点曲げ試験法を開発した。この試験法は， 成型コークスから採取した小さな試験片についても基礎 的な変形特性や強度特性を精度よく測定できること，共 鳴振動法のような動的測定法ではなく，静的な荷重方 法・測定方法を用いること，同一試験片についてヤング 係数と最大曲げ応力を同時に測定できることを特長とし ている.この試験法により各種の成型及び室炉ュークス の常温での最大曲げ応力とヤング係数とを測定し，これ らと気孔率などとの相関を求めた. さらに宮本らの砥 石などについての有限要素法による研究8) 10) を参照し て，気孔が不規則に分布する多孔体としてのコークスの 弾性挙動の統計的シミュレーション解析を行い，その結 果と実験的に求めたみかけの弾性係数とから，気孔を除 いたコークスのマトリックス部（炭素基質部）の弾性係 数を推定し，各種の成型及び室炉コークスの材質比較を 行つた.

\section{2. 実 験 方 法}

\section{$2 \cdot 1$ 試験片}

試料としては 3 種類の成型コークス，4 種類の室炉コ 一クス，1 種類の人造黒鉛電極（グラファイト）を用い た. Table 1 にその物性値を示す. 成型コークスでは真 密度の低下とともに気孔率が増加している。一方, 室炉

Table 1. Physical properties of cokes.

\begin{tabular}{|c|c|c|c|c|}
\hline \multirow{2}{*}{ Kind of Coke } & \multirow{2}{*}{$\begin{array}{l}\text { True } \\
\text { density } \\
\left(\mathrm{g} / \mathrm{cm}^{3}\right)\end{array}$} & \multicolumn{3}{|c|}{ Porosity $(\%)$} \\
\hline & & mean & s.d. & data \\
\hline Formed Coke A & 1.99 & 35.3 & 1.4 & 47 \\
\hline Formed Coke B & 1.85 & 36.5 & 3.3 & 86 \\
\hline Formed Coke C & 1.72 & 39.1 & 2.0 & 44 \\
\hline Conventional Coke $\mathrm{A}$ & 1.91 & 45.5 & 1.5 & 31 \\
\hline C.D.Q. & 2.00 & 48.4 & 1.8 & 44 \\
\hline Conventional Coke B & 1.97 & 50.7 & 3.2 & 23 \\
\hline Conventional Coke C & 1.97 & 59.2 & 2.1 & 5 \\
\hline Graphite & 2.10 & 17.6 & 1.1 & 8 \\
\hline
\end{tabular}

コークスでは成型炭 (30\%) 配合コークス（A）を除い て，真密度はほぼ $2 \mathrm{~g} / \mathrm{cm}^{3}$ に近い值を示している。

成型コークス試料は A (ピロー型)， B (マセック型), C (ピロー型) の 3 種で，その寸法はA種は $62 \times 45 \times$ $35 \mathrm{~mm}, \mathrm{~B}$ 種は $56 \times 56 \times 35 \mathrm{~mm}, \mathrm{C}$ 種は $83 \times 56 \times 42 \mathrm{~mm}$ である。

これらの成型コークスから板状の試験片を切り出した が，その寸法は成型コークスの大きさの制限から長さ $41 \mathrm{~mm}$, 幅 9〜11 mm, 厚さ $3 \sim 5 \mathrm{~mm}$ とした. 寸法関 係からみて，1個の成型コークスから，10 個程度の試 験片を切り出せるはずであるが，内部に巣やクラックが あるため，実際には平均 4 個程度にとどまつた。一方室 炉ュークスは $400 \times 100 \times 100 \mathrm{~mm}$ 大の大塊を $50 \times 50 \times$ $50 \mathrm{~mm}$ 大の小塊とした後, 同様な試験片を作成した。 こ の場合には気孔率が $50 \%$ 前後もあつて, 試験片の切り 出しにおける歩留りがきわめて悪く, 1 個の小塊から 2 〜 3 個の試験片しかえられなかつた.

以上のようにして切り出した試験片は, エメリー紙で 磨いた後水洗し， $150^{\circ} \mathrm{C} て ゙ ~ 12 \mathrm{~h}$ 以上乾燥した。乾燥後 試験片の重量と寸法を測定して, みかけ密度を算出し, 曲げ試験に供した。

\section{$2 \cdot 2$ 曲げ試験}

Fig. 1 に今回開発したミニチュア 4 点曲げ試験法に おける試験片寸法と負荷方法の原理を示す. 精度のよい 一様分布の純曲げを与えるため，ミニチュアベアリング により支持用ロールの摩擦抵抗を極力減らした. インス トロン型万能試験機を使用し，一定のクロスヘッド速度 で荷重をかけ，試験片中央のたわみ $\delta$ と荷重 $W$ との関係 を求めた。 ヤング係数 $E$ を求めるのには次の式11)用い た.

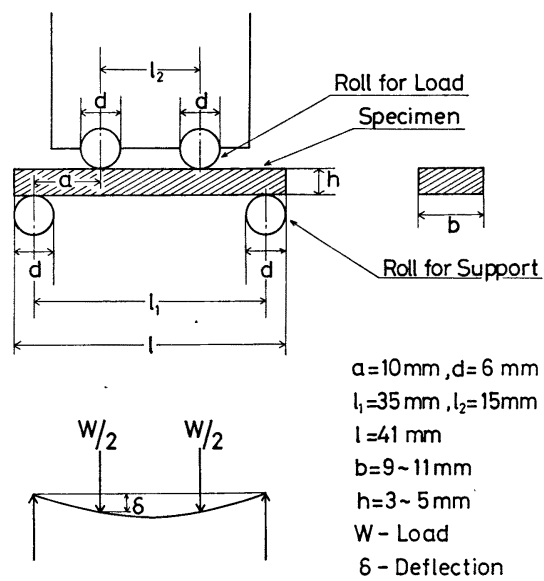

Fig. 1. Bending test. 


$$
E=\frac{3 a^{2}}{b h^{3}}\left(l_{1}-\frac{4}{3} a\right) \frac{W}{\delta}
$$

試験機の剛性はグラファイト試駼片の厚さhを変化さ せることにより求めた．Fig. 2 にその結果を示す. 各 荷重点でのたわみ $\delta$ と $1 / h^{3}$ との関係を下図のごとくプ ロットし，これらを連ねてえられる直線と縦軸 $\left(1 / h^{3}=\right.$ 0) との切片から試験機のたわみが測定される。これを 荷重に対してプロットすれば，上図のごとく荷重-試験 機のたわみ線図が求まる。この補正を施して求めたヤン グ係数の 值には， $h=2 \sim 7 \mathrm{~mm}, \quad b=5 \sim 20 \mathrm{~mm}$ の範囲 では，寸法効果はみとめられなかつた．またクロスヘッ ド速度の影響も $0.1 〜 10 \mathrm{~mm} / \mathrm{min}$ 範囲ではみられなか つたので，以後のクロスヘッド速度には $0.1 \mathrm{~mm} / \mathrm{min}$ を採用した。

最大曲げ応力 $\sigma_{\mathrm{b} \max }$ は, たとえば Fig. 3 に示すご とき荷重一たわみ曲線における最大荷重 $W_{\max }$ を用い て, 次の式11)で求めた.

$$
\sigma_{\mathrm{b} \max }=\frac{3 a}{b h^{2}} W_{\max }
$$

ポアソン比の測定は，試験片の下面に $7 \mathrm{~mm} \phi$ 円形へ ースのクロスゲージをアロンアルファで接着し, 曲げ試 験中に行つた。

\section{$2 \cdot 3$ 気孔率とモード気孔径}

真密度は JIS K 2151 の蒸溜水煮沸法により測定し, みかけの密度は試験片の重量と体積から求めた。この真
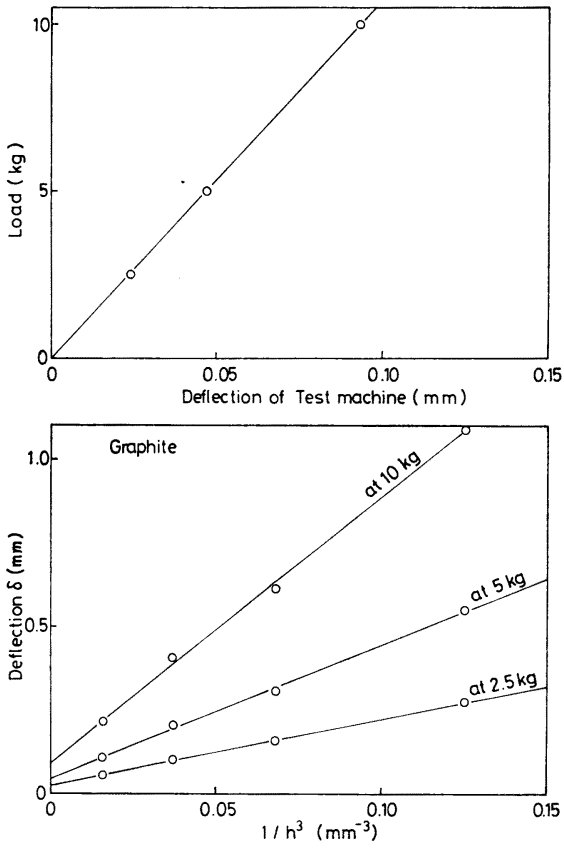

Fig. 2. Correction of Young's Modulus.
密度とみかけの密度から気孔率を求めた。

モード気孔径は，顕微鏡写真で個々の気孔径を測定 し，この度数分布から求めた。顕微鏡用試料は曲げ試験 片を半分に切り，樹脂に埋込んだ後，表面の気孔内にア ロンアルファを含浸させ，固化後研磨した. Photo. 1 にその顕微鏡写真の例を示す，黒つぽくややぼけている 部分 ( a ) あるいは灰色に見える部分 (b)が気孔である. 灰色の部分のらち小孔群または不規則網目のような様相 を呈するものはイナート組織とみて気孔径の測定からは 除いた．成型コークス $\mathrm{C}$ 種の場合，この網目状組織はす べて微細な気孔であるが，個々の気孔径の測定はできな かつた．それ以外の場合には気孔断面形状を屯ず棈円形 に近似し，その長径と短径を測定した後，その楕円と同 面積の円の半径を気孔径とした。測定は成型コークス A， B，室炉ュークスA， C.D.Q.の4 種について行 い，各コークスについてそれぞれ 2 個の顕微鏡試料の， それぞれ 56 個所について顕微鏡写真を撮り，このうち 任意の各 5 枚から気孔頻度を求めた. 測定した気孔の総 数は成型コークスで約 1000 個, 室炉ュークスで約 500 個である.

\section{3. 実 験 結 果}

\section{1 コークスの荷重たわみ曲線}

Fig. 3 にコークスの曲げ試験によつて得られた荷重一 たわみ曲線の代表的な測定例を示す．荷重は中央 2 荷重

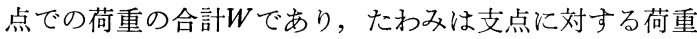
点の相対変位 $\delta$ である. 得られた荷重一たわみ曲線は $\mathrm{A}$, B 2 種類の型に大別できた． A 型は最大荷重以下の荷重

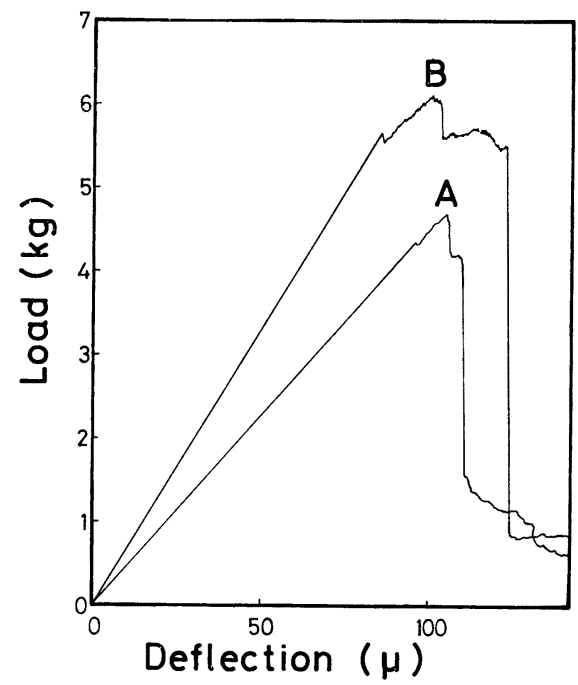

Fig. 3. Load-deflection curves. 


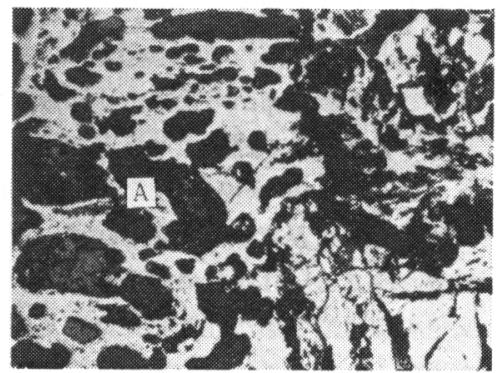

Formed Coke A

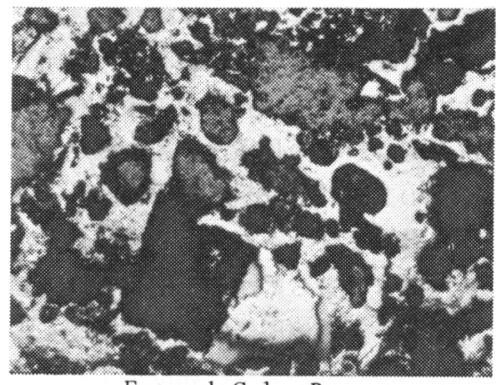

Formed Coke B

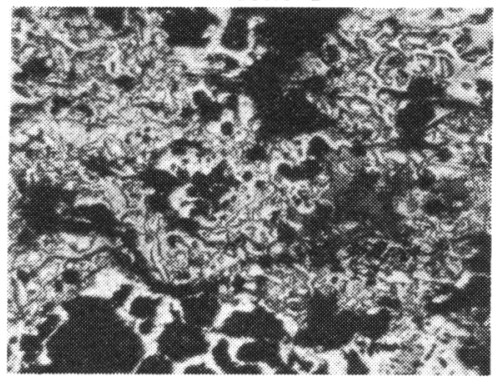

Formed Coke C

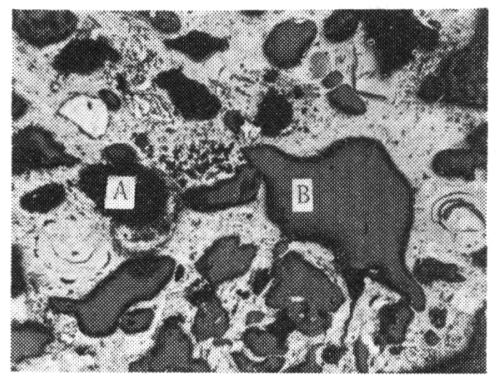

Conventional Coke A

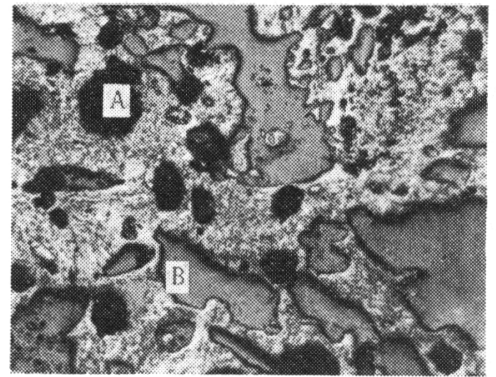

C.D.Q.

$200 \mu$

Photo. 1. Microstructures of formed and conventional cokes.

レベルで荷重の一時停滞あるいは降下（曲線上ではステ

ップ）が起こり，その後最大荷重を経て，荷重の急激な 低下を示した。一方 B 型は最大荷重の付近で脈動的な荷 重増減の繰り返しが続き（曲線上では踊り場, プラト 一)，その後荷重の低下が見られた・A型とB型はどのコ 一クス種にも見られたが，午の割合は，気孔率のもつと も低い成型コークスAで A 型曲線の出現率がもつとも多 く, 気孔率の増加とともに B 型曲線の占める比率が多く なつた。しかし成型コークス $\mathrm{C} の$ 場合には，上記の一般 傾向と異なり，核とんどB型曲線であつた。このことは 顕微鏡写真にも示唆されているょうに，このコークスの 構造, 組織が特殊なもので, 局部的小破壊が連続して生 じた後, 試験片全体の不安定を招くようなものであつた ことを示す.

\section{$3 \cdot 2$ コークスのヤング係数と最大曲げ応力}

Fig. 4 にヤング係数 $E$ と最大曲げ応力 $\sigma_{\mathrm{b}} \max$ との関

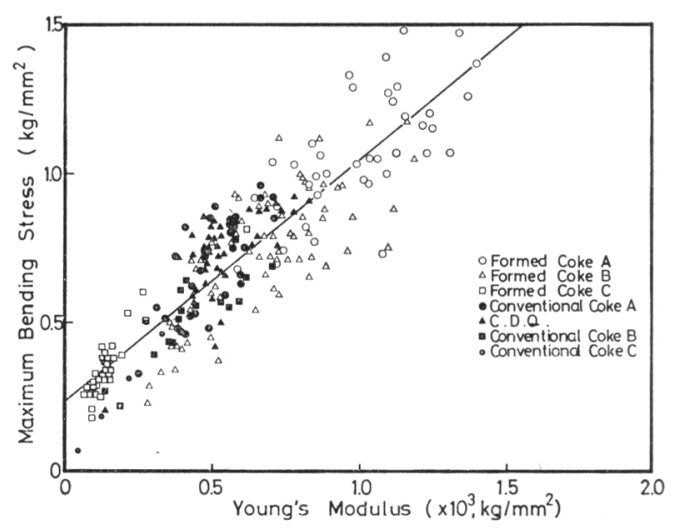

Fig. 4. Relation between Young's modulus and maximum bending stress.

係を示す。この㘠は, ヤング係数と最大曲げ応力との間 にコークス種によらず共通のかなりよい正の相関があ 
ることを示している.すなわち右上から左下に向かつて 成型コークスA，B，C.D.Q.，室炉ュークスA， B， $\mathrm{C}$, 成型コークス $\mathrm{C}$ の順に直線的に並ぶ。この回帰直線 を次式と図中の直線で示す.

$\sigma_{\text {b } \max }=0.23+0.0008 E\left[\mathrm{~kg} / \mathrm{mm}^{2}\right]$

$\left(5 \mathrm{~kg} / \mathrm{mm}^{2}<E<1400 \mathrm{~kg} / \mathrm{mm}^{2}\right) \cdots(3)$

ただし標本相関係数; $r=0.89$, 標本数; $n=245$

同様にヤング係数と最大曲げ忘力との関係が正の相関を 示古ものに鋳鉄などがある ${ }^{12)}$.鋳鉄は微小欠陷を内部に 多数含んでいて脆性を呈する材料とされ，コークスと類 似性が見られる。全体からみてコークスのみかけのヤン グ係数は成型コークスで $1000 \mathrm{~kg} / \mathrm{mm}^{2}$, 室炉コークスで $500 \mathrm{~kg} / \mathrm{mm}^{2}$ 前後の值を示し, 一方最大曲げ伈力は成型 コークスで $1.0 \mathrm{~kg} / \mathrm{mm}^{2}$, 室炉コークスで $0.6 \mathrm{~kg} / \mathrm{mm}^{2}$ 前後の值となる.いずれにしても，コークスのヤング係 数と最大曲げ念力との関係が正の相関を示すことから， ヤング係数から最大曲げ応力をある程度予測することが 可能と考えられる. またヤング係数と最大曲げ応力との この関係は，コークスの耐壊が荷重ではなく，导しろ変 形量によつて強く規定されることを示唆している.

Fig. 5 に最大曲げ㐫力と気孔率との関係を示す。こ の関係は負の相関を示し，成型コークスと室炉コークス とではやや異なつた関係があるように見られる。またグ ラファイトはコークスと比較してかなり高い最大曲げ応 力を示している.

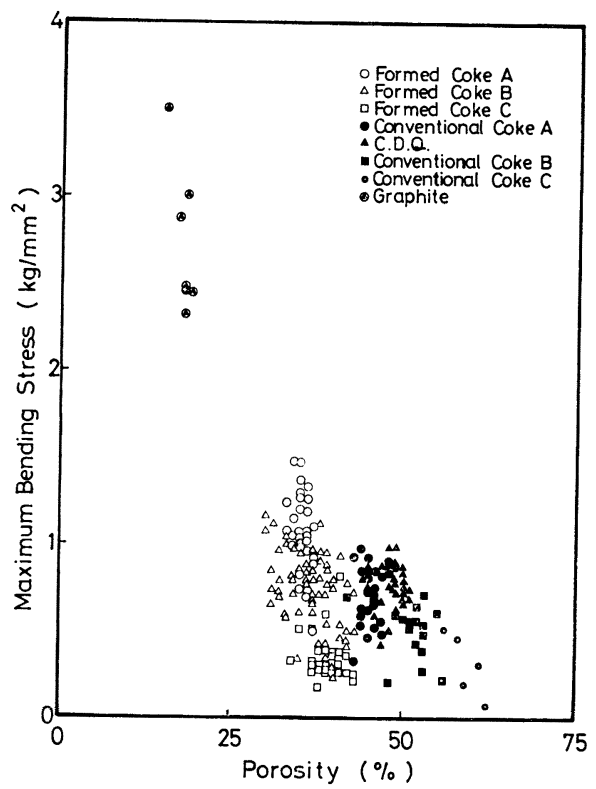

Fig. 5. Relation between maximum bending stress and porosity.

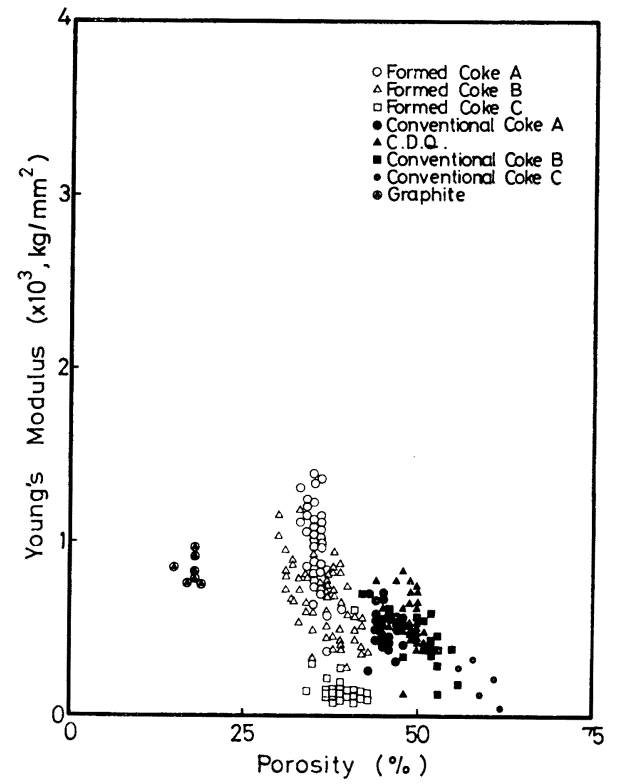

Fig. 6. Relation between Young's modulus and porosity.

Fig. 6 にヤング係数と気孔率との関係を示す. 最大 曲げ応力とヤング係数が正の相関を示すことから，Fig. 6 には Fig. 5 と同様な関係が見られる.

グラファイトの荷重一たわみ曲線には,荷重上昇時に高 荷重部で非線形挙動がみられた。 また Fig. 5，6の比較 からも推定されるように, Fig. 4 の最大曲げ応力とヤン グ係数之の関係では，グラファイトの実験值（図には示 していない）はコークスにおける直線関係からかなりず れていた．このことは上記の結果がコークスとグラファ イトの材質の違いによることを示唆したものと考える.

\section{3 コークスの気孔径分布}

Fig. 7〜8 に成型コークス及び室炉ュークスの顕微鏡 宣真から測定した気孔径分布を示す。後述のコークスの 弾性挙動のシミュレーションが 2 次元的であることと対 応して, 横軸に気孔径, 縦軸に断面積の重みをつけた気

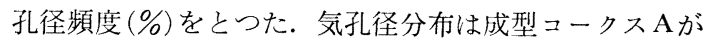
一番鋭いピークを示し, 気孔率の増加とともにしだいに 平坦になりながら大気孔側に移行していく。モード気孔 径は, 気孔径分布の最大頻度を示寸気孔径であるが，分 布をヒストグラムで得たので，以下のように，ピークを 示す区間の上下限值の 2 乗平均をとつた.

$$
\operatorname{Porosity}(\mathrm{P})=35 \% \quad \bar{r}_{\mathrm{i}}=\sqrt{\frac{27^{2}+45^{2}}{2}} \fallingdotseq 37(\mu)
$$



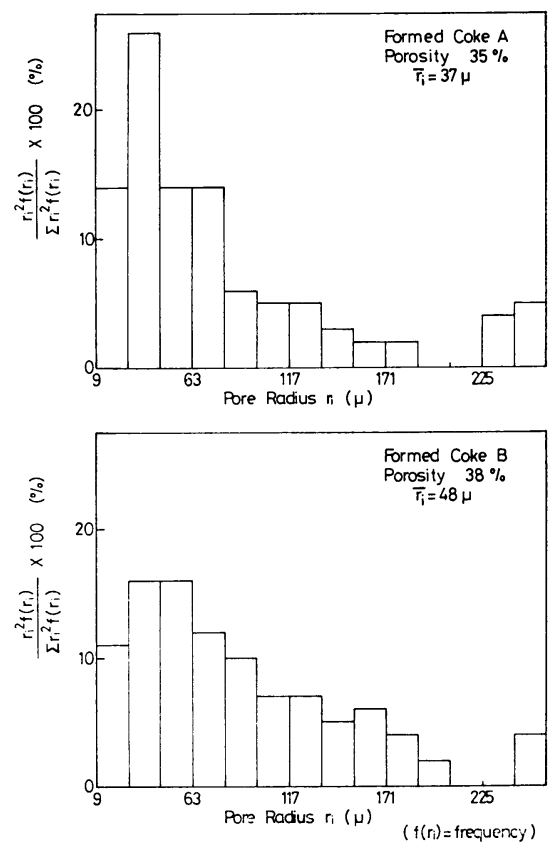

Fig. 7. Weighted frequency distributions of pore radius of formed coke.
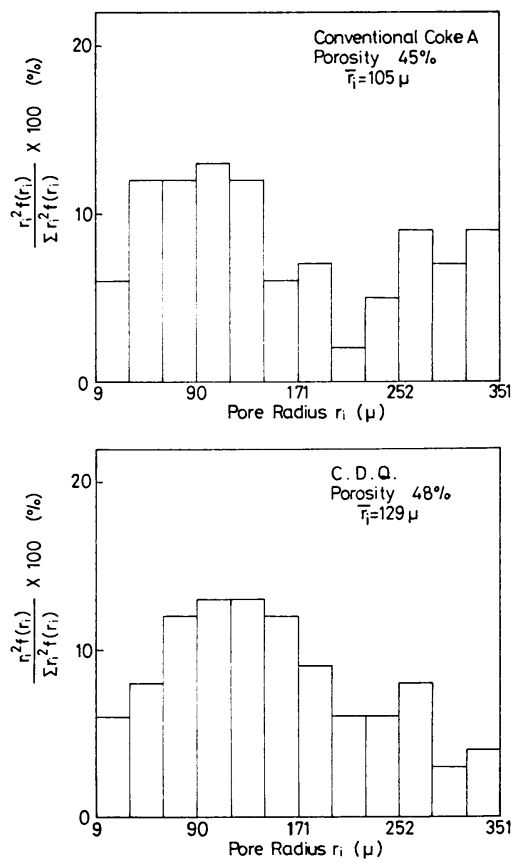

$\left(\mathrm{f}\left(\mathrm{r}_{\mathrm{i}}\right)=\right.$ frequency $)$

Fig. 8. Weighted frequency distributions of pore radius of conventional coke.

$$
\begin{aligned}
& \operatorname{Porosity}(\mathrm{P})=38 \% \quad \bar{r}_{\mathrm{i}}=\sqrt{\frac{27^{2}+63^{2}}{2}} \fallingdotseq 48(\mu) \\
& \text { " } \quad=45 \% \quad \bar{r}_{\mathrm{i}}=\sqrt{\frac{36^{2}+144^{2}}{2}} \fallingdotseq 105(\mu) \\
& \text { " } \quad=48 \% \quad \bar{r}_{\mathrm{i}}=\sqrt{\frac{63^{2}+171^{2}}{2}} \fallingdotseq 129(\mu)
\end{aligned}
$$

(6)，（7）の示すよらに，室炉コークスの場合は，かな り幅広い区間で平均をとることになつた。

\section{4. コークスの弾性挙動のシミュレーション}

\section{4 -1 コークスのモデル化}

Fig. 6 に示されるように,多孔質構造体としてのコー クスのヤング係数は，同一の気孔率において著しく変動 する. この変動は気孔径, 気孔の形状, 気孔の方向性及 び位置などがュークス内にランダムに分布することによ つて生じるものと考えられる.この考えをモデル化し， 微視的構造モデル8) 10) による解析法をコークスに適用 する．モンテカルロ法によつてこの不規則多孔体を解析 するためまずコークスを 2 次元構造体とし，これを構成 する単位として気孔のないマトリックス部と気孔を含む ポア部の 2 種を設定する. この 2 種の構造単位を 2 次元 的にランダムに配置し, 全体を有限要素法で 2 次元弾性 応力解析を行らといら操作をくり返すのである.

従来このような手法は，マトリックス部について既知 であるとした弾性係数から，多孔体のみかけの弾性係数 を推定するために開発されたよらである。しかしながら コークスの場合はマトリックス部の弾性係数が不明であ る、したがつて本研究では, 多孔体の弾性解析において この微視的構造モデルが十分成立するものと考光, こー クスのみかけのヤング係数とポアソン比から，マトリッ クス部のヤング係数とポアソン比を推定するのにこの解 析法を適用したのである. 実用的にはュークスは多孔体 のま使用されるから，みかけのヤング係数が重要であ ると考えることもできる，しかし製造条件の異なる成型 コークスと室炉コークスとを，単にみかけの物性值によ つてのみ比較することには問題がある．たとえば Fig. 6 に示されているように，成型コークスと室炉コークス とは気孔率の水準によつて二つのグループに分かれてい るように見える，これは成型ュークスでは，成型の直接 的効果としての気孔率の著しい低下と原料炭種にも依存 する材質の変化があり，この両者の影響がみかけの物性 值に現われることを示㖫するものである．したがつて気 
孔の影響を除いたコークスのマトリックス部のヤング係 数を推定できるならば，成型コークスと室炉コークスと の材質の機械的性質に関する比較を，また別の視角から 行らことが可能になると考えられる. このような理由に よりコークスの弾性挙動のシミュレーションを行つたの である. 以下にその解析手法を示す.

\section{2 計算方法}

Fig. 9 に本研究でのシミュレーションの方法を示 す. まずュークスを 2 次元構造体として考え, その構造 単位としてマトリックス部要素と気孔を含むポア部要素 とを設定する．次にマトリックス部のヤング係数とポア ソン比を仮定する，ポア部要素については，ある気孔率 でのモード気孔径は前述のよらに測定されているのでこ れを使えるが，この要素の大きさの決定に任意性が残 る. そこでここでは一つの ポア部要素の気孔面積率を $72 \%$ と仮定し，これとモード気孔径とからこの要素の大 きさを決定した。ポア部の気孔面積率が $72 \%$ といら仮 定は，この部の $1 / 4$ モデルの有限要素解析における要 素数 60 とのかねあいから導入したものであり, 要素数 をこれより多くすれば, $72 \%$ より大きくとることもでき る. ポア部のこの父孔面積率は気孔壁の厚みにも関係 し, また系全体の有限要素解析に打いて気孔率の上限界 を 72\% とすることにも対応するものであり，Fig. 5, Fig. 6 の測定值の範囲を十分に包含する. 以上により 与えられた気孔率でのポア部の有限要素解析に必要なデ

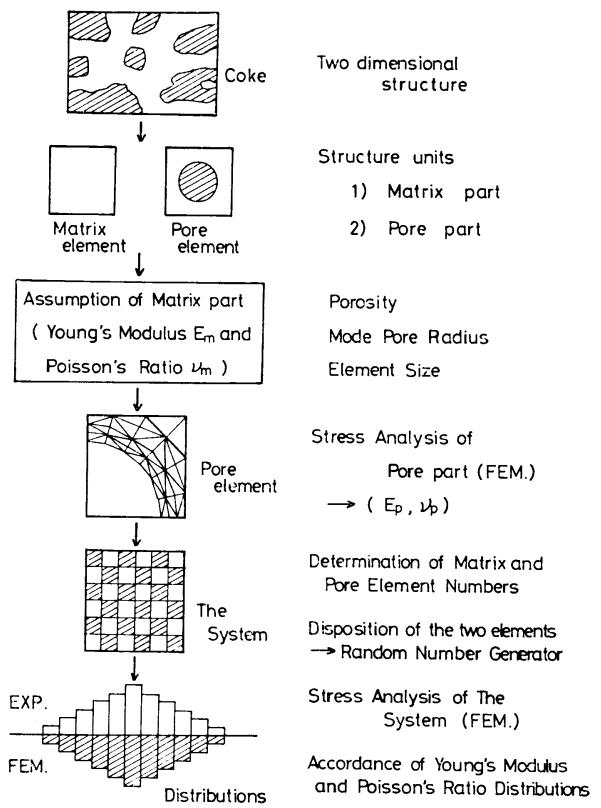

Fig. 9. Simulation method.

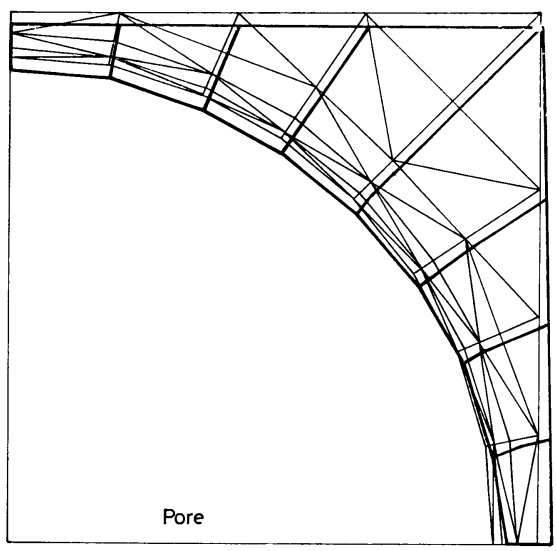

before deformation after deformation

Fig. 10. Deformation of pore element.

ータがそろつたので，これを使つて解析することにより ポア部のみかけのヤング係数とポアソン比を決定した.

Fig. 10 にポア部の 有限要素解析の 結果の一例を示 す。この図は 4 分割したポア部の変形状態を示すもの で，変形をやや誇張して示した．境界条件は一様分布変 位の一軸圧縮とし，細い線が変形前，太い線が变形後を 示す．気孔の形状は円形としたが，これを棈円形にし て，気孔断面形に括ける方向性を考慮することもでき る. ヤング係数は上下端の荷重方向変位とそこでの反力 との比より求め，ポアソン比は横方向変位の平均值と荷 重方向变位との比より求めた. Table 2 に使用したデー タを示す.ポア部の気孔面積率を一律に $72 \%$ としたた め，そのポアソン比はマトリックス部と同様に一定值を 示した.もしマトリックス部のヤング係数を同一にした ならば，ポア部のヤング係数も同一の值を示したはずで ある.このことから次に行ら系全体の解析には, 気孔率 によつて決定されるマトリックス部要素数とポア部要素

Table 2. Data of computer simulation.

\begin{tabular}{|c|c|c|c|c|c|c|}
\hline \multicolumn{3}{|c|}{ Number of elements } & \multicolumn{2}{|c|}{$\begin{array}{l}\text { Pore part } \\
\text { the system }\end{array}$} & \multicolumn{2}{|c|}{$\begin{array}{c}60 \\
7 \times 7=49\end{array}$} \\
\hline \multirow{2}{*}{ Matrix part } & \multicolumn{2}{|c|}{$E\left(\mathrm{~kg} / \mathrm{mm}^{2}\right)$} & 3000 & 2100 & 2000 & 2300 \\
\hline & \multicolumn{2}{|c|}{2} & \multicolumn{4}{|c|}{0.01} \\
\hline \multicolumn{3}{|c|}{$\begin{array}{ll}\text { Porosity, P } & (\%) \\
\text { Mode pore radius } & (\mu) \\
\text { Element size } & (\mu) \\
\end{array}$} & $\begin{array}{l}35 \\
37 \\
77\end{array}$ & $\begin{array}{r}38 \\
48 \\
100\end{array}$ & $\begin{array}{r}45 \\
105 \\
220\end{array}$ & $\begin{array}{r}48 \\
129 \\
270\end{array}$ \\
\hline \multicolumn{3}{|c|}{ Porosity of pore part (\%) } & \multicolumn{4}{|c|}{72} \\
\hline \multirow{2}{*}{ Pore part } & $E(\mathrm{k}$ & $\left.\mathrm{mm}^{2}\right)$ & 280 & 200 & 210 & 240 \\
\hline & $\nu$ & & \multicolumn{4}{|c|}{0.36} \\
\hline \multirow{2}{*}{\multicolumn{3}{|c|}{$\begin{array}{l}\text { Number of matrix } \\
\text { elements } \\
\text { Number of pore elements }\end{array}$}} & 25 & 23 & 18 & 16 \\
\hline & & & 24 & 26 & 31 & 33 \\
\hline
\end{tabular}


数との比が重要であることがわかる.

次に系全体の解析の手順を述べる. まず父孔率からマ トリックス部とポア部との要素数を沈定する。ここでは 系全体の要素数を $7 \times 7=49$ とした．次に乱数に従つて マトリックス部あるいはポア部の配置を決定する．以上 のデータを用いて系全体の有限要素解析を行うことによ り，みかけのヤング係数とポアソン比が決定される.

Fig. 11 に系全体のシミュレーションの結果の一例を 示す．ポア部要素と同様に境界条件は上下端で一様分布 変位の圧縮とした，図中の細い線が変形前，太い線が変 形後を表す。図中で変形が特に大きいところにポア部要 素が位置しているはずである.

なお，実験法が曲げ試験であるのに，シミュレーショ ンは压縮で行つているが，これは，弾性領域内では，曲 げ，圧縮のいずれも同じヤング係数，ポアソン比を用い てよいと考えたからである。

以上のようにして，ある配置でのみかけの+ング係数 とポアンン比を計算し，次に別の配置についてこのよう な計算を繰り返す。こうして，同一気孔率について各 25 の異つた配置についてそ犯ぞれ計算し,系全体のヤン グ係数とポアソン比を統計的に決定するのである。この さい計算值の分布と実測值の分布とが一致するように， マトリックス部のヤング係数とポアソン比をパラメータ 一として変化させることによつて，マトリックス部のヤ ング係数とポアソン比を決定することができる．解析に は成型コークスの 2 種と室炉ュークス 2 種, 計 4 種を用 いた. Table 2 において気孔率 $p=35 ， 38 ， 45 ， 48 \%$ は，それぞれ成型コークス $\mathrm{A}$ ，成型コークス $\mathrm{B}$ ，室炉コ ークス A， C. D. Q. に対応する. マトリックス部とポ

Loading Direction
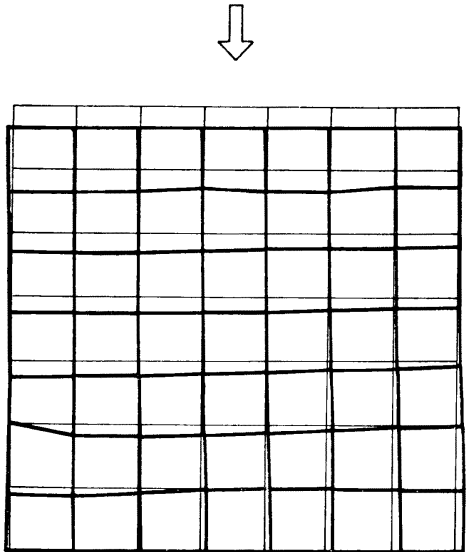

- before deformation

after deformation

Fig. 11. Deformation of the system.
ア部の要素数の比は気孔率 $35 \%$ でほぼ 1：1 となり, 気孔率の増加とともにポア部の要素数が増加する. 気孔 率 $72 \%$ の時すべてがポア部要素となり, 一力気孔率 0 \%の時にはすべてがマトリックス部要素となる.

\section{$\mathbf{4 . 3}$ 計算結果}

計算の実行にあたつては，各コークス種（すなわり，各 父孔率) ごとにマトリックス部のヤング係数をパラィー タとして変化させ，系全体のヤング係数の計算值の頻度 分布形をなるべく実測值のそれに近づけようにした。

一方ポアソン比については，その実測値の精度に不安が あるので，各コークス種ごとに頻度分布形を接近させる ことを考えず，さしあたりマトリックス部のポアソン比 を一定とし，その值は計算した全コークス種を通じて計 算值のばらつきが実測值のばらつき队に入るよらに選ん だ.Fig. 12 と Table 3 はマトリックス部のヤング係 数とポアソン比の值を Table 2 のようにとつたときの 計算結果である。

このよらにして得られた系全体のヤング係数の計算值 の平均值は, Table 3 に示すように，央測值のそ机より わずかに小さいが，両者はよい一致を示しているといえ よう。標準偏差の計算值は気孔率の増加とともに急速に 減少しているが，実測值は必ずしも同じ傾向になつてい ない。またポアソン比の計算値の平均値は実測値のそれ とよく一致しているとはいえないが，㓩述した計算上の

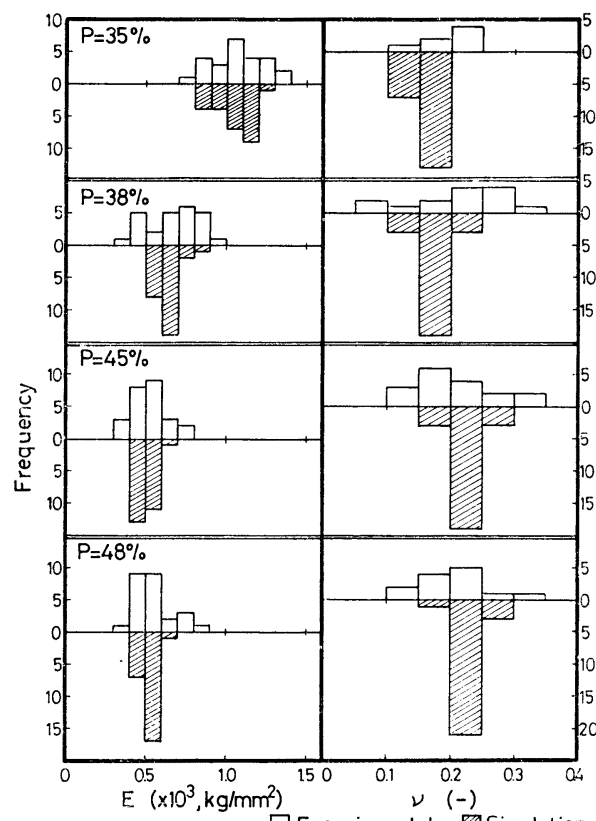

$\square$ Experimental Simulation

Fig. 12. Simulation result of young's modulus (E) and Poisson's ratio $(\nu)$. 


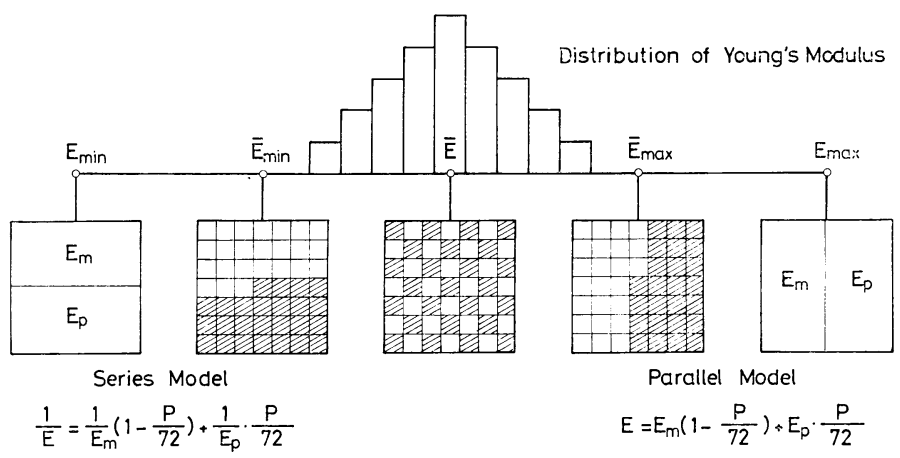

Fig. 13. Series model and parallel model.

Table 3. Young's modulus $E$ and Poisson's ratio ע of coke.

\begin{tabular}{|c|c|c|c|c|c|c|}
\hline \multicolumn{2}{|c|}{ Porosity } & $(\%)$ & 35 & 38 & 45 & 48 \\
\hline \multirow{3}{*}{$\begin{array}{c}E \\
(\mathrm{~kg} / \\
\left.\mathrm{mm}^{2}\right)\end{array}$} & EXP. & $\begin{array}{l}\text { Mean } \\
\text { s.d. } \\
\text { n.s. }\end{array}$ & $\begin{array}{r}1070 \\
160 \\
25\end{array}$ & $\begin{array}{r}660 \\
160 \\
25\end{array}$ & $\begin{array}{r}530 \\
100 \\
25\end{array}$ & $\begin{array}{r}540 \\
120 \\
25\end{array}$ \\
\hline & CAL. & $\begin{array}{l}\text { Mean } \\
\text { s.d. } \\
\text { n.d. }\end{array}$ & $\begin{array}{r}1040 \\
110 \\
25\end{array}$ & $\begin{array}{r}640 \\
70 \\
25\end{array}$ & $\begin{array}{r}500 \\
50 \\
25\end{array}$ & $\begin{array}{r}520 \\
30 \\
25\end{array}$ \\
\hline & \multicolumn{2}{|c|}{$\begin{array}{l}\text { Series model } \\
\text { Parallel model }\end{array}$} & $\begin{array}{r}500 \\
1610\end{array}$ & $\begin{array}{r}360 \\
1010\end{array}$ & $\begin{array}{l}320 \\
830\end{array}$ & $\begin{array}{l}350 \\
870\end{array}$ \\
\hline \multirow{2}{*}{$\nu$} & EXP. & $\begin{array}{l}\text { Mean } \\
\text { s.d. } \\
\text { n.s. }\end{array}$ & $\begin{array}{r}0.20 \\
0.30 \\
7\end{array}$ & $\begin{array}{r}0.21 \\
0.07 \\
14\end{array}$ & $\begin{array}{r}0.22 \\
0.07 \\
17\end{array}$ & $\begin{array}{r}0.21 \\
0.05 \\
13\end{array}$ \\
\hline & CAL. & $\begin{array}{l}\text { Mean } \\
\text { s.d. } \\
\text { n.d. }\end{array}$ & $\begin{array}{r}0.16 \\
0.02 \\
25\end{array}$ & $\begin{array}{r}0.18 \\
0.02 \\
25\end{array}$ & $\begin{array}{r}0.22 \\
0.02 \\
25\end{array}$ & $\begin{array}{r}0.24 \\
0.02 \\
25\end{array}$ \\
\hline
\end{tabular}

考虑条件は満足しておらり, 計算值が実測值を逸脱するこ 之はない。

\section{4 考察}

$4 \cdot 4 \cdot 1$ 複合則

計算結果ではマトリックス部のヤング係数はュークス 種によつて異なるということになつたが，マトリックス 部のヤング係数が同一で，気孔率が変化したときのコー クスのみかけのヤング係数の変化を，複合則 ${ }^{13)}$ を用いて 考えてみる.

複合則によれば，一般に分散型複合材料の弾性係数の 上下限は，それぞれ並列モデル，直列モデルによつて与 えられるとされている13).Fig. 13 にこれらのモデルを 示した。この複合則をマトリックス部要素とポア部要素 から成る系としてのコークスに適用する，Fig.14 はマ

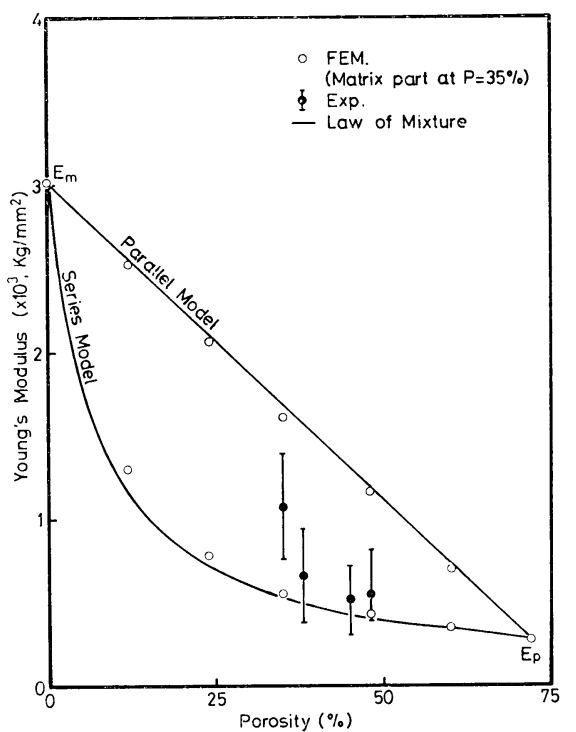

Fig. 14. Law of mixture.

トリックス部のヤング係数として，気孔率 $35 \%$ の場合 の值を用い，Fig. 6 のヤング係数と気孔率との関係に 適用した例である.実線はFig. 13 に記入した式によ る計算值で, 複合則によると上・下限值を与えるはずで ある。白丸が有限要素法による解であるが，これらの点 はすべて上述の上・ 一下限曲線よりやや内側に落ち, 複合 則にくらべて, 有限要素法による解が若干狭い上・下限 幅を与えることがわかる、これは，シミュレーションと 有限装素法による解析では，Fig. 13 に示したヤング係 数の最大値 $\left(E_{\max }\right)$ および最小值 $\left(E_{\min }\right)$ に対伈す る要素配列に，2 種の要素が共存する行または列が存在 することによるものである。また実測值は平均值および 最大・最小值で表示してあるが，気孔率 $35 \%$ の場合は 上・下限曲線の間に完全に括さまつている. 気孔率が 


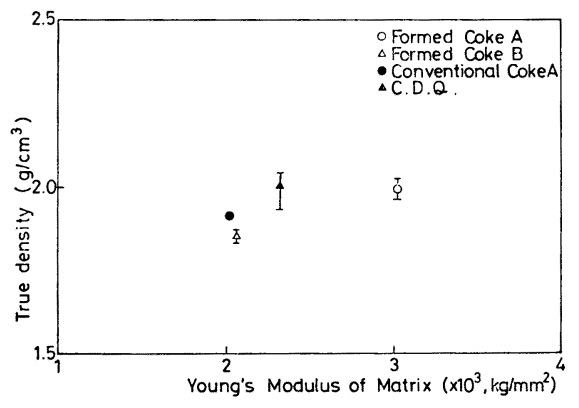

Fig. 15. Relation between Young's modulus of matrix and true density.

$35 \%$ 以上の場合も平均値は同じ上・下限曲線の間にあ るが，平均值以下の部分は下限曲線からはみ出してい る.これはマトリックス部のヤング係数の值を一定と仮 定したことによるものと考兄られ、以上の結果はこの 統計的シミュレーションと有限要素法による計算の合理 性を示し，あわせてマトリックス部のヤング係数をコー クス種ごとに変わるものとして評価することの必要性を 補足説明するものと考光られる.

$4.4 \cdot 2$ マトリックス部のヤング係数と真密度

Fig. 15 にマトリックス部のヤング係数と真密度との 関係を示す. 両者の間に正の相関の傾向があるよらにも 見られる.さらに成型コークスと室炉コークスとでは, その相関に違いが見られるようである。

\section{4. 結言}

ミニチュア 4 点曲げ試験法を開発し, 各種成型及び室 炉コークスについて基礎的な機械的性質を測定し，その 気孔率依存性を調べた。ささらに多孔体の弾性挙動のシミ ニレーション解析を行い，上記の結果を用いてマトリッ クス部のヤング係数を推定した. その結果次のような知 見を得た。

（1）ミニチュア曲げ試験法は, 従来のドラム試験法 と比べて, 成型コークスと室炉コークスとの常温に拈け る相違を材料強度の差で直接示すことができる.

（2）コークスの久かけのヤング係数は，コークス種 によらず，最大曲げ応力との間で共通の正の相関を示し た.これはヤング係数の大小から強度を予測する可能性 を示したものといえよう。

（3）コークスは強度值にばらつきの大きい多孔体で
あるが，その寸法，配置が不規則に分布する気孔の影響 を考慮したモデル化が可能であり，そのシミュレーショ ン解析から強度值のばらつきも理解でき, かつマトリッ クス部のヤング係数を推定できる.

（4）このマトリックス部のヤング係数の差に着目す るといら新しい観点から, 各種の成型および室炉コーク スの材質を比較することが可能になる.

本研究はコークスの常温における機械的性質を対象之 したが，その結果，この研究の延長線上にあつて，乙か も熱間強度といら究極的な目的に迫るための研究課題も あきらかになつたよらに思われる。高温曲げ試験による マトリックス部の高温に叔计る機械的性質の調査や，高 温反応による気孔状態の变化とその影響の調查などがそ れである.

終りに本研究の遂行にあたり有益な御助言をいただい た千葉大学井上勝也教授, 電気通信大学本間恭二助教 授, 東京大学生産技術研究所小倉公達助手, ならびに早 稲田大学大学院寺沢優一の諸氏に深謝する.

\section{交献}

1 ）城本義光, 松阔 宏, 本場崇一, 米沢賢一: $1-$ クスサーキュラー, 18 (1969), p. 126

2 ) 井田四郎, 西徹, 仲摩博至: コークスサーキ ュラ -21 (1972), p. 252

3 ) 井上勝也, 谷 秀夫: 燃協誌, 33 (1954), p. 587

4 ) 白石 稔, 熊井順二郎, 木村英雄, 吉田雄次: 燃協誌, 46 (1967), p.483

5 ) J. W. Patrick and $A . E$. Stagey: Fuel, 51 (1972), p. 81, p. 174, p. 206, 52 (1973), p. 27,54 (1975), p. 213 , p. 256

6 ）宮川巠夫，藤嶋一郎：燃協誌，54 (1975), p.983, 55 (1976), p. 30

7 ) 永井交雄, 佐藤和郎, 神田忠泰: 材料科学, 12 (1975), p. 56

8 ) 宮本 博, 本間恭二: 材料科学, 12 (1975), p. 12

9 ) 宮本 博, 尾田十八, 坂田信二: 機械学会誌, 77 (1974), p. 146

10）宮本 博, 尾田十八, 坂田信二: 機械学会論交集, 41 (1975), p. 748

11) 日本機械学会編：機械工学便覧改訂第五版 (1968)， 4 分册, p. 42

12）沖進，加山延太郎：溶解鋳造 - 鋳物（1962）, p. 176, [朝倉書店]

13) 藤井太一: 材料, 25 (1976), p. 199 